\title{
Nutritional risks among not exclusively breastfed infants in the first 6 months of life
}

\author{
Horacio F. González, M.D. ${ }^{a}$, Mabel Carosella, M.D. ${ }^{b}$ and Adriana Fernández, M.D. ${ }^{c}$
}

\begin{abstract}
Breast milk is the ideal food for infants and its benefits can be observed in the short and long term. In crisis situations, breastfeeding should be promoted the most because it is one of the most cost-effective interventions aimed at reducing infant morbidity and mortality. In addition to the multiple advantages of breast milk in the mother-child bond and biological and immune properties, the most relevant characteristic of breast milk is that it covers all nutritional needs. When breastfeeding is not possible, the World Health Organization recommendsinfant formula as the first option. The second option is diluted cow's milk, which entails the risk for nutritional deficiency that should be strictly monitored and timely resolved. When infants are fed with diluted cow's milk, they are mainly at risk for iron, zinc, vitamin $\mathrm{A}, \mathrm{D}, \mathrm{C}$, and $\mathrm{E}$, amino acid, and essential fatty acid deficiency.

Key words: breastfeeding, infant nutritional physiological phenomena, breast milk substitutes, micronutrients/deficiency, macronutrients.
\end{abstract}

http:/ / dx.doi.org/10.5546/ aap.2021.eng.e582

E-mail address:

Horacio F. González, M.D.: horaciofgonzalez@ gmail.com

Funding:

Mead Johnson

Nutrition Argentina facilitated the meetings and technical details of this study.

\section{Conflict of interest: \\ The manuscript was written with the help of all authors in an autonomous manner; the company did not interfere with the editorial management or the final article. The authors state that their only relationship with Mead Johnson Nutrition was their participation in conferences and symposiums organized by the company, as in others carried out by other companies.}

Received: 12-16-2020 Accepted: 5-28-2021 changes in the quality of feeding, a situation that health care providers should be alert to.

Breast milk is the ideal food since birth, and its benefits can be seen in the short and long term. It has an impact on children's comprehensive health, growth, and development, and creates a protection against future diseases. Breastfeeding is considered one of the most cost-effective interventions aimed at reducing infant morbidity and mortality. ${ }^{3}$

Argentina has established legal instruments to promote breastfeeding from different perspectives; however, they do not seem to be enough to warrant their practice. ${ }^{4}$ According to the latest National Survey on Nutrition and Health (2019), 96.9\% of infants started breastfeeding, and with no significant differences in the analyzed sociodemographic factors. ${ }^{5}$ This is a high prevalence compared to global epidemiological data and is consistent with the positive consideration of breastfeeding among the Argentine population..$^{3-6}$ In spite of this, exclusive breastfeeding is maintained until 6 months of life only in $43.7 \%$ of infants. ${ }^{7}$

Among infants who are not exclusively breastfed, it is important to know the type of milk received given the important impact it may have on health. According to the National Survey on Breastfeeding of 2017, among infants younger than 6 months not exclusively breastfed, the first option is infant formula (59\%), followed by milk from the mother and child plan (MCP) or powder cow's milk fortified with iron, zinc, and vitamin C (20\%), and, lastly, unfortified cow's milk (8\%). ${ }^{7}$

Breast milk is the "gold standard" and hard to mimic due 
to its special characteristics and the emotional bond represented by breastfeeding, beyond its composition: it is a "biological dialog" whereby an infant conveys information to their mother about their needs and the mother responds by altering milk's amount and composition. In addition, it is a vehicle for immune, microbiological, and psychological communication between the mother and her child. ${ }^{8}$ It is a live, unique food that varies from mother to mother, provides macro- and micronutrients, more precisely, oligosaccharides, bacteria, and bacterial metabolites that modulate the gut microbiota composition, which, in turn, modulates gastrointestinal tract and immune system development. ${ }^{9-10}$

In recent years, the evidence suggests that breastfeeding also plays a major role in noncommunicable diseases programming in the long term. ${ }^{3}$

Organizations like the World Health Organization (WHO), the United Nations International Children's Emergency Fund (UNICEF), the American Academy of Pediatrics (AAP), and the Spanish Society of Pediatrics (Asociación Española de Pediatría, AEP) recommend exclusive breastfeeding on demand during the first 6 months of life. ${ }^{11-14}$ If breastfeeding is not possible, infant formula should be indicated.

According to the United Nations' Codex Alimentarius, breast milk substitutes are food products proposed as partial or total breast milk substitutes. Infant formula is defined as liquid or powdered form product for use as a substitute of breast milk in meeting the normal nutritional requirements of infants. It should have proven safety and nutritional suitability to favor an adequate growth and development. Based on this definition, whole cow's milk is not considered a breast milk substitute in the first 6 months of life due to its potential harmful effects on health. ${ }^{15}$

The Food Guidelines (2001) and the Infant Nutrition Guidelines by the Ministry of Health (2006), published by the Sociedad Argetnina de Pediatria, propose, for the first 6 months of life and in the case of not being able to continue with breastfeeding, infant formula as the first option, diluted cow's milk (in half) with 5\% sugar and $2 \%$ oil as the second option, and diluted cow's milk (in two-thirds) fortified or enriched with iron and vitamins $\mathrm{A}$ and $\mathrm{C}$, if possible, as the third option. ${ }^{6,17}$

Micronutrient deficiency, including vitamin A, iron, zinc, amino acids, and essential fatty acids, are the most relevant deficiencies worldwide. ${ }^{18}$
When breastfeeding or the administration of an adequate breast milk substitute are not possible, the nutritional status worsens.

The objective of this study is to provide updated information about the nutritional risk of infants younger than 6 months who are not exclusively breastfed.

This study analyzes the following aspects:

- Proteins in breast milk, baby formula, and cow's milk.

- Fatty acids.

- Micronutrients.

- Cow's milk and iron deficiency.

\section{Proteins in breast milk, infant formula, and cow's milk}

Breast milk proteins are the ideal source of amino acids for infant growth, have a higher biological value and, being homologous, they lack antigenic ability.

Protein content in breast milk varies during breastfeeding; from 1.4-1.6 g/ $100 \mathrm{~mL}$ in the first months to $0.8-1.0 \mathrm{~g} / 100 \mathrm{~mL}$ after this period. Serum proteins (PS) account for $80 \%$ of total proteins; the remaining $20 \%$ is casein. Such ratio is also modified over time and reaches 50\%:50\% during late breastfeeding. ${ }^{19}$

The main serum proteins in breast milk are alpha-lactalbumin (critical for lactose synthesis), lactoferrin and IgA (important bioactive and immune molecules). ${ }^{20,21}$

Lactoferrin accounts for $15-20 \%$ of serum proteins, plays a major antibacterial role (by inhibiting bacterial growth, adhesion, and translocation), and modulates epithelial growth. ${ }^{22,23} \operatorname{IgA}$ is the main immunoglobulin present in breast milk and confers an important antimicrobial protection. Other immune factors found in breast milk include leukocytes, cytokines, lysozymes, and these warrant an adequate gut microbiota development, thus favoring food tolerance. ${ }^{24}$

Protein fat content in cow's milk $(3.5 \%)$ is 3 times higher than that of breast milk. The main protein in cow's milk is casein $(80 \%)$ ). It can be categorized into sub-classes: alpha-casein, the main type in cow's milk, and beta-casein, the main type in breast milk.

The lactoferrin in cow's milk has lower antibacterial effects and does not favor iron absorption, like that present in breast milk. In cow's milk, the total amount of immunoglobulins is lower than in breast milk, and the main immunoglobulin is IgG. ${ }^{25}$ 
Given its high protein and sodium content, the intake of unmodified cow's milk causes a high renal solute load and a risk for increased water loss in urine and dehydration in infants. ${ }^{26}$

Protein content in infant formula is approximately $1.5 \mathrm{~g} / 100 \mathrm{~mL} .{ }^{9}$ For infant formula to have a similar quality to breast milk, they contain $60 \%$ of serum proteins and $40 \%$ of casein. Serum proteins in infant formula contain betalactoglobulin. The addition of bovine lactoferrin to infant formula has improved its function in recent years because it prevents contamination..$^{27,28}$

\section{Carbohydrates}

The main carbohydrate in breast milk is lactose (90\%), and its fat content is approximately $7 \mathrm{~g} / 100 \mathrm{~mL}$. Lactose favors calcium and mineral absorption and is the precursor of oligosaccharide production.

Breast milk contains small amounts of glucose and galactose and more than 200 structures of oligosaccharides, whose composition and proportion varies depending on different factors.

Human milk oligosaccharides (HMO) are the third component, following lactose and lipids, and its concentration varies depending on the different breastfeeding periods (5-20 g/L in mature milk and 20-25 g/L in colostrum). $\mathrm{HMO}$ are minimally digested in the small intestine and the undigested fraction serves as a prebiotic. The presence of different HMO stimulates specific bacterial growth that have beneficial effects and inhibits the development of harmful ones. HMO affect cell responses and modulate epithelial apoptosis and cell proliferation and differentiation. Certain HMO reduce proinflammatory cytokine expression and have an impact on the development of diseases related to the immune system. ${ }^{29}$

Several bacteria have been detected in breast milk, thus forming a true seeding by providing more than $10^{5}$ bacteria per day from the maternal gut, an effect of the entero-mammary pathway. ${ }^{30,31}$

Cow's milk contains $4.5 \mathrm{~g} / \mathrm{L}$ of lactose and only scarce amounts of glucose, galactose, and oligosaccharides.

Most infant formulas contain lactose (5.4$8.2 \mathrm{~g} / 100 \mathrm{~mL}$ ) and a lower proportion of maltodextrins. Infant formula contains added fructooligosaccharides and galactooligosaccharides as complex oligosaccharides that function as prebiotics. 32

Some infant formulas currently include some fucosylated HMO that have been identified in breast milk.

\section{Fatty acids}

Breast milk contains 3-5\% of lipids that provide $40-50 \%$ of total energy and essential fatty acids. Triglycerides (TG) account for $98 \%$ of total lipids. ${ }^{33}$ Phospholipids (PL) are not abundant but very relevant: they are part of milk fat globule membrane, contain essential fatty acids, and are positively associated with neurodevelopment, immune system modulation, and antimicrobial properties. ${ }^{34,35}$

Fatty acids are derived from endogenous synthesis in the mammary gland and uptake from maternal plasma. ${ }^{33}$

The most abundant fatty acids in breast milk are monounsaturated fatty acids (MUFA) $(43 \%)$ and saturated fatty acids (SFA) (40\%). Total n-3 and n-6 polyunsaturated fatty acids (PUFA) account for $2.3 \%$ and $14.7 \%$, respectively, whereas docosahexaenoic acid (DHA) accounts for 0.18$0.30 \%$ and arachidonic acid (ARA), $0.38-0.45 \%{ }^{36}$

Cow's milk contains more than $60 \%$ of SFA, $30 \%$ of MUFA, and only $4 \%$ of PUFA, but no DHA. ${ }^{37}$ This is a very important limitation for cow's milk as a breast milk substitute due to the effect of PUFA on neurodevelopment. DHA and ARA are essential fatty acids due to the limited enzymatic maturation necessary to synthesize them in the first months of life. ${ }^{38}$ DHA accounts for $25 \%$ of total fatty acids in the human brain cortex, $30 \%$ in the retina, and $60 \%$ in photoreceptor cells. ${ }^{39}$

The industry of infant formula as a breast milk substitute has modified its fatty acid profile. The percentage of SFA and PUFA was adapted to international recommendations and maintain the DHA:ARA ratio. ${ }^{15,40}$ Their absorption and entrance into the bloodstream have been measured in the levels observed in breast milk..$^{41,42}$

Diluted cow's milk at 50\% with the addition of $2 \mathrm{~g}$ of oil and $5 \mathrm{~g}$ of sugar per $100 \mathrm{~mL}$ should be the last option, and every effort should be made to supplement any potential deficiency. For example, the addition of $2 \mathrm{~g}$ of sunflower oil would provide linoleic oil (54\%) and oleic oil (33\%), but only $0.2 \%$ of linolenic oil and no DHA. Diluted cow's milk at $50 \%$ provides $1.65 \mathrm{~g}$ of lipids per $100 \mathrm{~mL}$ and only traces of $\mathrm{n}-3$.

The profile of fatty acid malnutrition has been described and demonstrated an increase in $n-6$ and n-9, to the detriment of n-3, particularly DHA, with the consequences described above. ${ }^{43}$ 


\section{Micronutrients}

Breast milk is an accurate source of micronutrients, some of which are modified depending on the maternal nutritional status. ${ }^{44}$

Vitamins $\mathrm{A}$ and $\mathrm{B} 12$ require an adequate maternal intake to reach the desired levels for infant nutrition. 45

Vitamin D level is low in breast milk and should be supplemented preventively during the first month of life (400 IU/day). ${ }^{46}$ If the breastfeeding mother restricts animal products in her diet, she should receive supplementation for vitamin B12, zinc, iron, etc. to prevent the negative consequences on infant development. ${ }^{47}$

Vitamin and mineral intake from infant formula is regulated by the Codex Alimentarius; in general, it refers to the ideal composition of breast milk. ${ }^{15}$

The level of vitamin D in unfortified cow's milk is low, and even lower if diluted. The level of vitamins $\mathrm{A}$ and $\mathrm{C}$ in unfortified whole cow's milk is low (31 retinol equivalents [RE] and $0.94 \mathrm{mg} / 100 \mathrm{~g}$, respectively) and minimal when diluted. Breast milk contains $64 \mathrm{RE}$ and $5 \mathrm{mg} / 100 \mathrm{~g}$, respectively. ${ }^{37}$

Breast milk provides a calcium:phosphorus ratio of $2: 1,11$ thus ensuring its optimal use. The ratio in cow's milk is $1: 1$, which may lead to hypocalcemia due to secondary hyperparathyroidism. ${ }^{48}$

\section{Cow's milk and iron deficiency}

A negative aspect of cow's milk consumption among infants is its association with iron deficiency. Iron plays a major role in the body, especially in relation to oxygen transport, immune system, and the brain. ${ }^{49,50}$

Iron stores at birth are enough until approximately 4 months old.

Without preventive supplementation or fortification, it is difficult to achieve an adequate iron nutrition. ${ }^{51}$ Bioavailability in breast milk is high. ${ }^{52}$

TABLE 1. Composition of breast milk, infant formula, whole cow's milk, and diluted cow's milk

\begin{tabular}{|c|c|c|c|c|}
\hline Nutrient/100 mL & Breast milk & Infant formula* & Whole cow's milk** & $\begin{array}{l}\text { Diluted cow's milk }+ \\
5 \% \text { sugar }+2 \% \text { oil }^{* * *}\end{array}$ \\
\hline Energy (Kcal) & 70 & $60-70$ & 61 & 68 \\
\hline Proteins (g) & $0.9-1$ & $1.3-2$ & 3.4 & 1.7 \\
\hline Casein $(\%)$ & 20 & 40 & 80 & 80 \\
\hline Serum proteins $(\%)$ & 80 & 60 & 20 & 20 \\
\hline Carbohydrates (lactose) (g) & 6.9 & $4-6$ & 4.6 & 2.3 \\
\hline Fat $(\mathrm{g})$ & $3.8(3.5)$ & $2.6-4.2$ & 3.4 & 2.7 (with added oil) \\
\hline Iron (mg) & 0.05 & 0.3 & 0.05 & 0.025 \\
\hline Zinc (mg) & 0.17 & 0.32 & 0.38 & 0.19 \\
\hline Sodium (mg) & 16 & $13-36$ & 49 & 25 \\
\hline Potassium (mg) & 53 & $36-108$ & 152 & 76 \\
\hline Calcium (mg) & 32 & 32 & 119 & 59 \\
\hline Phosphorus (mg) & 14 & 16 & 93 & 47 \\
\hline Calcium/phosphorus & $2-1$ & $2-1$ & $1-1$ & $1-1$ \\
\hline Vitamin $\mathrm{A}(\mathrm{RE})^{* * * *}$ & $30-64$ & $42-126$ & 31 & 15.5 \\
\hline Ascorbic acid (mg) & 5 & 7 & 0.94 & 0.47 \\
\hline Vitamin D (IU) & $15-20$ & $28-56$ & $5-10$ & $2.5-5$ \\
\hline Vitamin E (mg of alpha-tocopherol) & 1.38 & $0.5-1.25$ & 0.1 & 0.05 \\
\hline Vitamin B12 $2^{* * * *}(\mathrm{mg})$ & 0.58 & 0.30 & 0.35 & 0.18 \\
\hline Osmolality (mOsm) & 286 & 258-309 & 350 & 187 \\
\hline
\end{tabular}

* $\quad$ Food and Agriculture Organization of the United Nations, World Health Organization. Standard for infant formula and formulas for special medical purposes intended for infants. In Codex Alimentarius. International Food Standards. 2007. [Accessed on: June $30^{\text {th }}$, 2021]. Available at: http:/ / www.fao.org/fao-who-codexalimentarius/ sh-proxy/en/ ?lnk=1\&url=https $\% 253 \mathrm{~A} \% 252 \mathrm{~F} \% 252 \mathrm{Fw}$ orkspace.fao.org $\% 252 \mathrm{Fsites} \% 252 \mathrm{Fcodex} \% 252 \mathrm{FStandards} \% 252 \mathrm{FCXS} \% 2 \mathrm{~B} 72-1981 \% 252 \mathrm{FCXS} 072 \mathrm{e} . p d f$

** Jenssen RG, Kroger M. The importance of milk and milk products in the diet. In: Miler GD, Jarvis JK, McBean LD (eds). Handbook of Dairy Foods and Nutrition. $2^{\text {nd }}$ ed. Boca Raton (Fla): CRC press; 1999:1-55.

*** Ministerio de Salud. Dirección Nacional de Maternidad e Infancia. Sucedáneos de la Leche Materna. In Guías Alimentarias para la población infantil. Buenos Aires: MINSAL; 2006: 27.

**** Variables according to maternal intake. 
Infants fed with cow's milk have a higher risk for iron deficiency. ${ }^{26,53-55}$ The replacement of breast milk with cow's milk has a negative association with iron deficiency and a positive association with infant formula; ${ }^{56}$ this is attributed to their fortification. In addition, studies of unfortified infant formula showed a better iron nutrition compared with subjects who received cow's milk, which evidences that other mechanisms are involved in it. ${ }^{57}$

The different types of amino acid combinations in proteins also account for the effects on iron absorption. Cysteine is the only amino acid capable of increasing iron absorption. ${ }^{49}$ Casein ( $80 \%$ in cow's milk) has a low level of cysteine (3 $\mathrm{mg} / \mathrm{g}$ of protein), but a level 10 times higher $(30 \mathrm{mg} / \mathrm{g}$ of protein) in serum proteins $(80 \%$ in breast milk). ${ }^{58}$

In alpha-lactalbumin ( $22 \%$ of serum proteins in breast milk but only $3.5 \%$ in cow's milk), the level of cysteine is $48 \mathrm{mg} / \mathrm{g}$ of proteins. ${ }^{58}$ Therefore, such benefit is also observed in infant formula.

The state of iron stores regulates its absorption, which is also affected by diet factors: ascorbic acid favors absorption, while calcium hinders it. ${ }^{49}$

A high level of calcium in cow's milk inhibits iron absorption. For breast milk and cow's milk, iron absorption was $48 \%$ and $19.5 \%$, respectively. The addition of calcium to breast milk inhibits iron absorption. The differences in calcium content account for $70 \%$ of the difference in iron bioavailability. ${ }^{59}$ In infant formula, calcium levels are similar to those of breast milk.

Iron requirements for infants in the second trimester are $0.7 \mathrm{mg} /$ day. The iron level in infant formula is $6-12 \mathrm{mg} / \mathrm{L}$. Such high intake covers the requirements. ${ }^{26}$

Another concern in relation to cow's milk consumption in the first year of life is blood loss through the digestive tract. Healthy infants have a minimal blood loss in feces. Such blood loss was estimated using labeled substances at $0.59 \mathrm{~mL} /$ day ${ }^{57}$ Infants fed with cow's milk have a higher induced loss: $1.7 \mathrm{~mL} /$ day; in the same infants but fed with infant formula, it reduced to $0.3 \mathrm{~mL} /$ day. A blood loss of $1.7 \mathrm{~mL} /$ day equals an iron loss of $0.53 \mathrm{mg} /$ day, which hinders the possibility of a net balance of $0.7 \mathrm{mg} /$ day that is necessary to prevent iron deficiency. ${ }^{57}$ It has been estimated that, in $40 \%$ of infants fed with cow's milk, blood loss increases significantly.

Higher losses have been reported at a lower prevalence $(<1 \%)$, e.g., hemorrhagic proctocolitis associated with allergic immune reactions. ${ }^{60}$

Table 1 shows the composition of breast milk, infant formula, whole cow's milk, and diluted cow's milk.

\section{Final remarks}

Breastfeeding is the ideal food for infants.

When the indication of breast milk substitutes is justified, the most adequate option should be selected based on age, socioeconomic conditions, and local availability. Infant formula is the first option when breastfeeding is not possible.

Whole cow's milk is contraindicated in the first year of life, and suggested diluted cow's milk pose a risk for nutritional deficiencies in the infant that should be closely monitored and timely supplemented.

The main risks for infants fed with diluted cow's milk include iron, zinc, vitamin A, D, $\mathrm{C}$, and $\mathrm{E}$, amino acid, and essential fatty acid deficiency.

In this group of infants, full supplementary feeding is recommended before 6 months old (but not before 4 months old) to improve micronutrient intake, accompanied with iron and vitamins A, C, and D supplementation as per recommendations. ${ }^{61-63}$

\section{REFERENCES}

1. Swinburn BA, Kraak VI, Allender A, Atkins VJ, et al. The Global Syndemic of Obesity, Undernutrition, and Climate Change: The Lancet Commission report. Lancet. 2019; 393(10173):791-846.

2. Jones G, Steketee RW, Black RE, Bhutta ZA, et al. How many child deaths can we prevent this year? Lancet. 2003; 362(9377):65-71.

3. Victora CG, Bahl R, Barros AJD, França GVA, et al. Breastfeedinginthe $21^{\text {st }}$ century:Epidemiology, mechanisms, and lifelong effect. Lancet. 2016; 387(10017):475-90.

4. Ley 26.873. Lactancia Materna. Promoción y Concientización Pública. Buenos Aires, Argentina; 5 de agosto de 2013. [Accessed on: June 1 ${ }^{\text {st }}$, 2021]. Available at: http: / / servicios.infoleg.gob.ar/infolegInternet / anexos/215000-219999/218212/norma.htm

5. Argentina. Ministerio de Salud y Desarrollo Social. $2^{\circ}$ Encuesta Nacional de Nutrición y Salud. ENNyS 2: Indicadores seleccionados de salud y nutrición población materno-infantil. 2019. [Accessed on: June 1 $1^{\text {st }}, 2021$ ]. Available at: https: / / bancos.salud.gob.ar/ recurso/2degencuesta-nacional-de-nutricion-y-salud-indicadoresseleccionados

6. Liga dela Leche Argentina, Voices. Mitos y creencias acerca de la lactancia materna en Argentina. 2015. [Accessed on: June $1^{\text {st }}$,2021]. Availableat: https: / / www.sap.org.ar/docs / congresos_2015/Lactancia/Cilley_Encuesta_opinion_ publica.pdf

7. Argentina. Ministerio de Salud. Dirección Nacional de Maternidad, Infancia y Adolescencia. Situación de la lactancia materna en Argentina. 2015. [Accessed on: April $\left.19^{\text {th }}, 2017\right]$. Availableat:https: / / bancos.salud.gob.ar/ sites / default / files / 2018-10/0000001135cnt-lactancia-materna- 
argentina-2015.pdf

8. Victora C. La lactancia como diálogo biológico. Arch Argent Pediatr. 2017; 115(5):413-4.

9. Eriksen KG, Christensen SH, Lind MV, Michaelsen KF. Human milk composition and infant growth. Curr Opin Clin Nutr Metab Care. 2018; 21(3):200-6.

10. Pannaraj PS, Li F, Cerini C, Bender JM, et al. Association between breast milk bacterial communities and establishment and development of the infant gut microbiome. JAMA Pediatr. 2017; 171(7):647-54.

11. Comité de Lactancia Materna de la Asociación Española de Pediatría. Recomendaciones sobre lactancia materna. 2012. [Accessed on: April 1', 2017]. Available at: http:/ / www. aeped.es / sites / default / files / 201202-recomendacioneslactancia-materna.pdf

12. World Health Organization, UNICEF. Global strategy for infant and young child feeding. Geneva: WHO; 2003. [Accessed on: April 1st, 2017]. Available at: http://apps. who.int/iris/ bitstream/10665/42590/1/9241562218.pdf

13. Kramer MS, Kakuma R. Optimal duration of exclusive breastfeeding. Cochrane database Syst Rev. 2012; (8):CD003517.

14. World Health Organization. Essential Nutrition Actions: improving maternal, newborn, infant and young child health and nutrition. Geneva: WHO; 2013.

15. Codex Alimentarius. International Food Standards. FAO-WHO. STANDARD FOR INFANT FORMULA AND FORMULAS FOR SPECIAL MEDICAL PURPOSES INTENDED FOR INFANTSCXS72-1981Formerly CAC/ RS 72-1972. Adopted as a worldwide standard in 1981. Amended in 1983, 1985, 1987, 2011, 2015, 2016, 2020. Revised in 2007. [Accessed on: June $1^{\text {st }}, 2021$ ]. Available at: http: / / www.fao.org/fao-who-codexalimentarius/sh-proxy/en/ ?lnk $=1 \&$ url $=$ https $\% 253 \mathrm{~A} \% 252 \mathrm{~F} \% 252 \mathrm{Fw}$ orkspace.fao.org $\%$ 252Fsites $\%$ 252Fcodex $\%$ 252FStandards $\% 252$ FCXS $\% 2$ B721981\%252FCXS_072e.pdf

16. Comité de Nutrición. Guía de alimentación para niños sanos se 0 a 2 años. Sociedad Argentina de Pediatría, 2001. [Accessed on: June 1 1, 2021]. Available at: https:/ / www. sap.org.ar/docs / publicaciones/alim_0a2.pdf

17. LongoE, Albaizeta D. Guías Alimentarias para la Población Infantil. Consideraciones para los equipos de salud, 2006. Buenos Aires: Ministerio de Salud; 2006.

18. FAO, FIDA, UNICEF, PMA, OMS. El estado dela Seguridad Alimentaria y la Nutrición en el mundo. Fomentando la resiliencia climática en aras de la seguridad alimentaria y la nutrición. Roma: FAO; 2018. [Accessed on: June 1st 2021]. Available at: http:/ / www.fao.org/3/I9553ES/i9553es.pdf

19. Lönnerdal, B. Nutritonal and physiologic significance of human milk proteins. Am J Clin Nutr. 2003; 77(6): S153743.

20. Paddon-Jones D, Coss-Bu JA, Morris CR, Phillips SM, Wernerman J. Variation in Protein Origin and Utilization: Research and Clinical Application. Nutr Clin Pract. 2017; 32(1 Suppl):S48-57.

21. Lönnerdal B. Bioactive Proteins in Human Milk: Health, Nutrition, and Implications for Infant Formulas. J Pediatr. 2016; 173(Suppl):S4-9.

22. Woodman T, Strunk T, Patole S, Hartmann B, et al. Effects of lactoferrin on neonatal pathogens and Bifidobacterium breve in human breast milk. PLoS One. 2018; 13(8):e0201819.

23. Telang S. Lactoferrin: A Critical Player in Neonatal Host Defense. Nutrients. 2018; 10(9):1228.

24. Lönnerdal B. Infant formula and infant nutrition: bioactive proteins of human milk and implications for composition of infant formulas. Am J Clin Nutr. 2014; 99(3):S712-7.

25. Stelwagen K, Carpenter E, Haigh B, Hodgkinson A, Wheeler TT. Immune components of bovine colostrum and milk. J
Anim Sci. 2009; 87(13 Suppl):3-9.

26. Ziegler EE. Adverse effects of cow's milk in infants. Nestle Nutr Workshop Ser Pediatr Program. 2007; 60:185-99.

27. GreccoC, Ronayne deFerrerP.Composición delas fórmulas Infantiles. In:Setton D, Fernández A. Nutrición en Pediatría: bases para la práctica clínica en niños sanos y enfermos. Ciudad Autónoma de Buenos Aires: Panamericana; 2014. Pages.127-33.

28. Manzoni P, Rinaldi M, Cattani S, Pugni L, et al. Bovine lactoferrin supplementation for prevention of late-onset sepsis in very low birth-weight neonates: a randomized trial. JAMA. 2009; 302(13):1421-8.

29. Gridneva Z, Rea A, Tie WJ, Lai CT, et al. Carbohydrates in human milk and body composition of term infants during the first 12 months of lactation. Nutrients. 2019; 11(7):1472.

30. Tocca MC, BurgosF, Fernández A, Giglio N, etal. Ecosistema intestinal en la infancia: rol de los "bióticos". Arch Argent Pediatr. 2020; 118(4):278-85.

31. Soto A, Martín V, Jiménez E, Mader Z, et al. Lactobacilli and bifidobacteria in human breast milk: influence of antibiotherapy and other host and clinical factors. J Pediatr Gastroenterol Nutr. 2014; 59(1):78-88.

32. Moro G, Minoli I, Mosca M, Fanaro S, et al. Dosage-related bifidogenic effects of galacto and fructooligosaccharide in formula-fed term infants. J Pediatr Gastroenterol Nutr. 2002; 34(3):291-5.

33. Innis SM. Impact of maternal diet on human milk composition and neurological development of infants. Am J Clin Nutr. 2014; 99(3):734S-41.

34. Zou X, Ali AH, Abed SM, Guo Z. Current knowledge of lipids in human milk and recent innovations in infant formulas. Curr Opin Food Sci. 2017; 16:28-39.

35. Demmelmair H, Koletzko B. Lipids in human milk. Best Pract Res Clin Endocrinol Metab. 2018; 32(1):57-68.

36. Miliku K, Duan QL, Moraes TJ, Becker AB, et al. Human milk fatty acid composition is associated with dietary, genetic, sociodemographic, and environmental factors in the CHILD CohortStudy. Am JClin Nutr. 2019;110(6):137083.

37. Jenssen RG, Kroger M. The importance of milk and milk products in the diet. In: Miler GD, Jarvis JK, McBean LD (eds). Handbook of Dairy foods and Nutrition. Boca Raton, Fla: National Dairy Council. CRC press; 1999.Pages.1-55.

38. González HF, Visentin S. Nutrientes y neurodesarrollo: lípidos. Arch Argent Pediatr. 2016; 114(5):472-6.

39. GuesnetP, AlessandriJM.Docosahexaenoicacid (DHA) and the developing central nervous system(CNS)-Implications for dietary recommendations. Biochimie. 2011; 93(1):7-12.

40. Koletzko B, Bergmann K, Brenna JT, Calder PC, et al. Should formula for infants provide arachidonic acid along with DHA? A position paper of the European Academy of Paediatrics and the Child Health Foundation. Am J Clin Nutr. 2020; 111(1):10-6.

41. Visentin S, Vicentin D, Magrini G, Santandreu F, et al. Red blood cell membrane fatty acid composition in infants fed formulas with different lipid profiles. Early Hum Dev. 2016; 100:11-5.

42. Miller MR, Seifert J, Szabo NJ, Clare-Salzler M, et al. Erythrocyte membrane fatty acid content in infants consuming formulas supplemented with docosahexaenoic acid (DHA) and arachidonic acid (ARA): an observational study. Matern Child Nutr. 2010; 6(4):338-46.

43. Marín MC, DeTomásME,MercuriO,Fernández A, deSerres $\mathrm{CT}$. Interrelationship between protein-energy malnutrition and essential fatty acid deficiency in nursing infants. $A m$ J Clin Nutr. 1991; 53(2):466-8.

44. Neville MC, Anderson SM, McManaman JL, Badger TM, et al. Lactation and neonatal nutrition: defining and refining 
the critical questions. J Mammary Gland Biol Neoplasia. 2012; 17(2):167-88.

45. Matamoros N, Visentin S, Ferrari MG, Falivene M, et al. Contenido de vitamina $\mathrm{A}$ en la leche materna madura y su adecuación a las recomendaciones nutricionales en el lactante. Arch Argent Pediatr. 2018; 116(2):146-9.

46. Wagner CL, Greer FR; American Academy of Pediatrics Section on Breastfeeding; American Academy of Pediatrics Committee on Nutrition. Prevention of rickets and vitamin D deficiency in infants, children, and adolescents. Pediatrics. 2008; 122(5):1142-52.

47. Comité Nacional de Nutrición. Dietas vegetarianas en la infancia. Arch Argent Pediatr. 2020; 118(4):S130-41.

48. Specker BL, Tsang RC, Ho ML, Landi TM, Gratton TL. Low serum calcium and high parathyroid hormone levels in neonates fed 'humanized' cow's milk-based formula. Am J Dis Child. 1991; 145(8):941-5.

49. Thorsdottir I, Thorisdottir AV. Whole cow's milk in early life. Nestle Nutr Workshop Ser Pediatr Program. 2011; 67:2940.

50. Thorisdottir AV, Gunnarsdottir I, Palsson GI, Gretarsson SJ, Thorsdottir I. Iron status and developmental scores in 6-year-oldshighlights ongoing need to tackleiron deficiency in infants. Acta Paediatr. 2013; 102(9):914-9.

51. Berglund S, Domellöf M. Meeting iron needs for infants and children. Curr Opin Clin Nutr Metab Care. 2014; 17(3):26772.

52. Lönnerdal B. Development of iron homeostasis in infants and young children. Am J Clin Nutr. 2017; 106(Suppl 6):1575S-80.

53. Thorisdottir AV, Thorsdottir I, Palsson GI. Nutrition and Iron Status of 1-Year Olds following a Revision in Infant Dietary Recommendations. Anemia. 2011; 2011:986303.

54. Oliveira MA, Osório MM, Raposo MC. Concentração de hemoglobina e anemia em crianças no Estado de Pernambuco, Brasil: fatores sócio-econômicos e de consumo alimentar associados. Cad Saude Publica. 2006; 22(10):216978 .
55. MaleC, Persson LA, Freeman V, Guerra A, et al. Prevalence of iron deficiency in 12-mo-old infants from 11 European areas and influence of dietary factors on iron status (EuroGrowth study). Acta Paediatr. 2001; 90(5):492-8.

56. Thorisdottir AV, Ramel A, Palsson GI, Tomassson $\mathrm{H}_{\text {, }}$ Thorsdottir I. Iron status of one-year-olds and association with breast milk, cow's milk or formula in late infancy. Eur J Nutr. 2013; 52(6):1661-8.

57. Ziegler EE. Consumption of cow's milk as a cause of iron deficiency in infants and toddlers. Nutr Rev. 2011;69(Suppl 1):S37-42.

58. Layman DK, Lönnerdal B, Fernstrom JD. Applications for $\alpha$-lactalbumin in human nutrition. Nutr Rev. 2018;76(6):44460.

59. Hallberg L, Rossander-Hultén L, Brune M, Gleerup A. Bioavailability in man of iron in human milk and cow's milk in relation to their calcium contents. Pediatr Res. 1992; 31(5):524-7.

60. Elizur A, Cohen M, Goldberg MR, Rajuan N, et al. Cow's milk associated rectal bleeding: a population based prospective study. Pediatr Allergy Immunol. 2012;23(8):76670.

61. Fewtrell M, Bronsky J, Campoy C, Domellöf M, et al. Complementary Feeding: A Position Paper by the European Society for Paediatric Gastroenterology, Hepatology, and Nutrition (ESPGHAN) Committee on Nutrition. J Pediatr Gastroenterol Nutr. 2017; 64(1):119-32.

62. Munns CF, Shaw N, Kiely M, Specker BL, et al. Global Consensus Recommendations on Prevention and Management of Nutritional Rickets.JClin Endocrinol Metab. 2016; 101(2):394-415.

63. Comité Nacional de Hematología, Oncología y Medicina Transfusional y Comité Nacional de Nutrición. Deficiencia de hierro y anemia ferropénica. Guía para su prevención, diagnóstico y tratamiento. Arch Argent Pediatr. 2017; 115(Supl 4):s68-82. 